\title{
Diversity and bioactive potentials of culturable heterotrophic bacteria from the surficial sediments of the Arabian Sea
}

\author{
Abdulaziz Anas ${ }^{1} \cdot$ Charulatha Nilayangod $^{1}$ - C. Jasmin ${ }^{1} \cdot$ Saradavey Vinothkumar $^{1}$ - P. S. Parameswaran ${ }^{1}$. \\ Shanta Nair ${ }^{1}$
}

Received: 7 July 2016/Accepted: 19 October 2016/Published online: 11 November 2016

(c) The Author(s) 2016. This article is published with open access at Springerlink.com

\begin{abstract}
Marine sediments accommodate plethora of diverse microorganisms with varying ecological functions. In the present study, we isolated bacteria from surficial sediments of south east Arabian Sea (AS) and evaluated their bioactive potentials. A total of 131 isolates belonging to the phylum: $\gamma$-Proteobacteria (63\%), Bacillales (34\%) and Micrococcaceae (3\%) were isolated. Among these, about $40 \%$ of the isolates showed the presence of secondary metabolite biosynthetic genes such as PKS or NRPS or both. Organic extracts of nearly $50 \%$ of these organisms were cytotoxic to human breast cancer MCF-7 cells and were bactericidal to human pathogens, Escherichia coli and Pseudomonas sp., while $20-30 \%$ of them were bactericidal to Vibrio sp. and Staphylococcus sp. too. In all, 8 isolates, belonging to Pseudomonas spp., Bacillus sp. and/or Lysinibacillus sp. displayed high level of bactericidal/cytotoxic properties. The study proposes AS sediment as a rich source for microorganisms with prospective bioactive molecules.
\end{abstract}

Keywords Diversity · Bacteria, antibacterial · Cytotoxic · Oxygen minimum zone $\cdot$ Arabian Sea

\section{Introduction}

Marine microorganisms are exposed to a variety of environmental conditions and are considered as a vast untapped reservoir of metabolic diversity and overwhelming source

Abdulaziz Anas

anas@nio.org

1 CSIR-National Institute of Oceanography, Regional Centre, Kochi, Kerala 682 018, India of novel bioactive compounds. Recent reports of repeated isolation of known metabolites from terrestrial micro/macro organisms indicate that we have almost exhausted this source for novel therapeutics (Daniel 2004; Debbab et al. 2010; Sponga et al. 1999). Contrary to this, several novel bioactive metabolites have recently been reported from different marine organisms. It is also possible that many of these compounds, initially isolated from marine invertebrates, could be produced by associated microorganisms (Mehbub et al. 2014). It is believed that 10-20\% of the bacteria isolated from marine environment have biotechnological (Armstrong et al. 2001; Lemos et al. 1985; Zheng et al. 2005) or medicinal (antimicrobial, cytotoxic, antioxidant, antiangeogenesis, antidiabetic, etc.) (Debbab et al. 2010; Thakur et al. 2005; Zheng et al. 2005) properties. Mostly, these reports are based on the bioprospecting studies of microorganisms associated with mangroves, sponges, sea weeds, etc., leaving aside the larger portion of marine environment, i.e., sediments and other extreme environments almost untouched (Beedessee et al. 2015; Santos-Gandelman et al. 2014).

Oxygen minimum zones (OMZ) are subsurface oceanic regions characterized by lethargic circulation of oxygenpoor waters $(<8 \mu \mathrm{M})$, high primary productivity, intense denitrification and high oxygen demand due to decaying sinking organic matter (Banse et al. 2014). Nearly 59\% of world OMZ are being reported from the water column of Arabian Sea at depths of 100-1000 m (Banse et al. 2014). The intensity of OMZ may extend up to the coastal water $(<20 \mathrm{~m})$, in response to climatic changes, upwelling, river discharge and natural or anthropogenic fertilization (Paulmier and Ruiz-Pino 2009). OMZ alters the chemical composition of the surrounding environment and also induce stress on the organisms (Childress and Sieibel 1998; Schneider and Bush-Brown 2003). Previous studies on 
OMZ have concentrated primarily on the diversity of microorganisms in these waters/sediments (Bryant et al. 2012; Divya et al. 2010, 2011) and their functional role in nitrogen cycle (Paulmier and Ruiz-Pino 2009). Though OMZ constitute only about $0.1 \%$ of the total oceanic volume, about $30-40 \%$ of the total oceanic nitrogen loss is estimated to occur within it. It is believed that this denitrification is mediated by denitrifying and anaerobic ammonia oxidizing bacteria (anammox) (Codispoti et al. 2001; Lam et al. 2009; Woebken et al. 2008). Recent studies have also reported microbial suphate reduction and sulphur oxidation in OMZ (Canfield et al. 2010). However, the bioactive potential of these microorganisms have not been studied yet in detail. An earlier study from our group had reported the enzymatic diversity of bacteria isolated from the sediments of Arabian sea OMZ region (Divya et al. 2010). In the present study, sediment samples were collected from perennial or seasonal OMZ regions of AS and reported the diversity and bioactive properties of associated heterotrophic bacteria.

\section{Methodology}

\section{Sample collection, separation of microorganisms}

Sediment samples collected from three different depths (50, 100 and $200 \mathrm{~m}$ ) of Cochin transect of Arabian Sea
Fig. 1 Map showing sampling locations across Kochi Transect of Arabian Sea

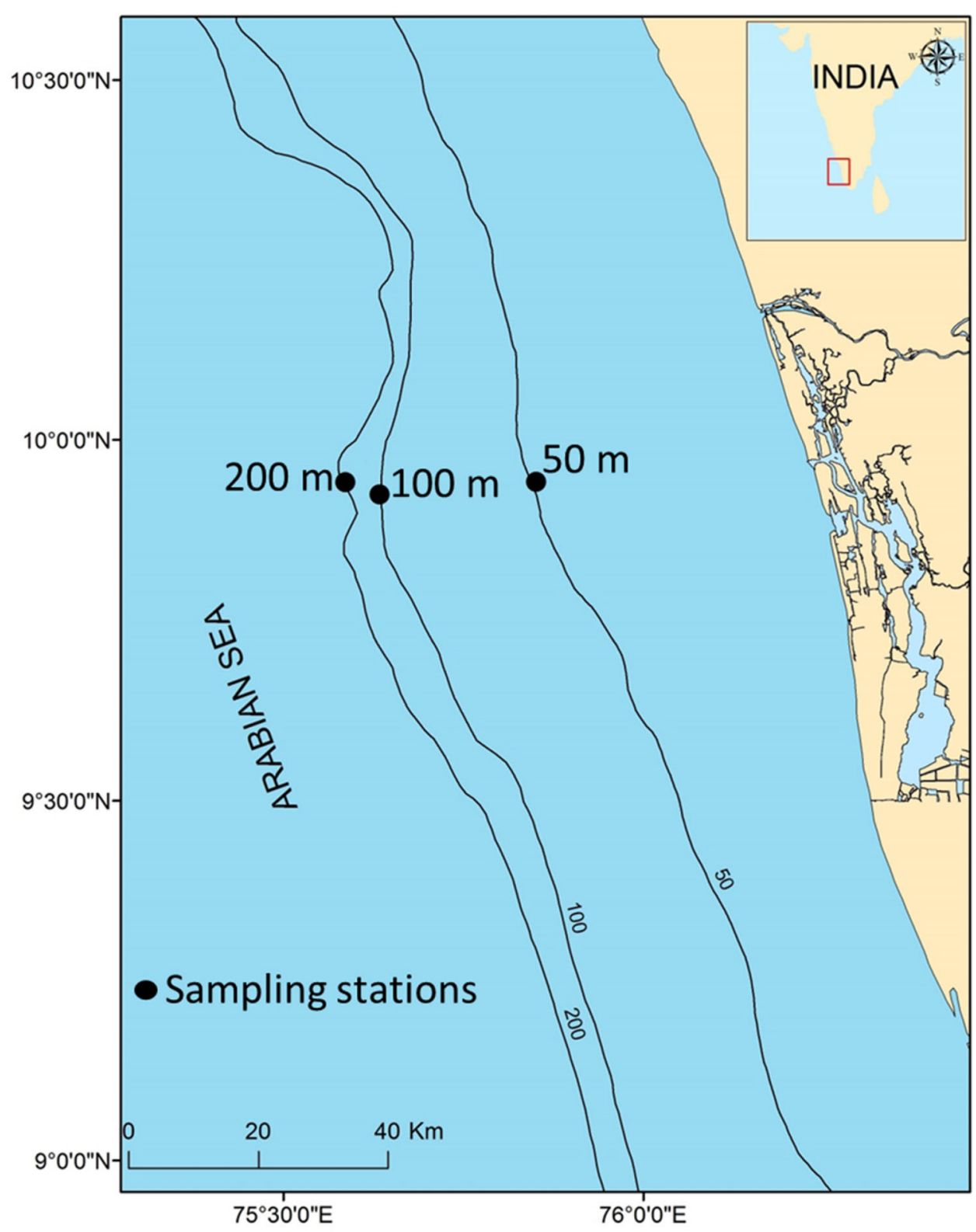


(Fig. 1) during FORV Sagar Sampada cruise (No 289) was used for the isolation of bacteria. Aliquots of sediment samples (100 g) from Grab sampler were removed aseptically into sterile polypropylene bottles and maintained at $4{ }^{\circ} \mathrm{C}$ until further analysis. Total microorganisms were separated from sediment samples following differential centrifugation with slight modifications (Fieseler et al. 2006). Briefly, sediment samples were mixed with sterile seawater and disintegrated mechanically using a mortar and pestle. The bacteria released into seawater were separated by filtering sequentially through nylon mesh (ca. $200 \mu), 70$ and $30 \mu$ filter cups. The remaining sediment particles in the filtrate was separated by repeated centrifugation at $100 \mathrm{~g}$ for $10 \mathrm{~min}$, and the bacteria were separated by centrifugation at $12,000 \mathrm{~g}$ for $30 \mathrm{~min}$ (Biofuge Stratos, Heraeus Germany). The presence of microorganisms was confirmed microscopically after staining an aliquot with DAPI. The microorganisms were preserved in artificial seawater containing $20 \%$ glycerol at $-80{ }^{\circ} \mathrm{C}$.

\section{Isolation and purification of Microorganisms}

The microorganisms separated from sediment as mentioned above were serially diluted up to $10^{6}$ and $100 \mu \mathrm{l}$ from each dilution was spread over the surface of Oligo (trypton 0.05 ; yeast extract 0.005 ; sodium glycerol phosphate 0.01 and agar $1.5 \%$ ), Basal (trypton 0.5 ; yeast extract 0.1 ; glucose 0.2 and agar $1.5 \%$ ), Starch casein nitrate (starch 1.0; casein 0.03; $\mathrm{K}_{2} \mathrm{PO}_{4} 0.2 ; \mathrm{KNO}_{3} 0.2 ; \mathrm{MgSO}_{4}$ $7 \mathrm{H}_{2} \mathrm{O} 0.005 ; \mathrm{FeSO}_{4} \cdot 2 \mathrm{H}_{2} \mathrm{O} 0.002 ; \mathrm{CaCO}_{3} 0.001$ and agar $1.5 \%$ ) and starch casein (starch 1.0; casein 0.1 and agar $1.5 \%$ ) medium. All the media were prepared in $50 \%$ sea water and adjusted to $\mathrm{pH} 7.6 \pm 0.2$. The plates were incubated at $28 \pm 2{ }^{\circ} \mathrm{C}$ up to 3 weeks and morphologically different colonies were isolated and purified at every $48 \mathrm{~h}$.

\section{Identification of microorganisms}

Based on morphological characteristics, 40 representative isolates were selected and identified by $16 \mathrm{~S}$ rRNA gene sequencing. Genomic DNA was extracted from overnight grown cultures following standard phenol-chloroform method, and the quality of DNA was checked on $0.8 \%$ agarose gel (Sambrook and Russel 2001). The 16S rRNA gene of the bacteria ( $1465 \mathrm{bp}$ ) was amplified using universal primers [27F: AGAGTTTGATC(AC)TGGCTCAG and 1492R: GGTTACCTTGTTACGACTT] (Lane $1991)$ in a $25 \mu \mathrm{l}$ reaction volume containing $1 \mu \mathrm{l}$ DNA (50-100 ng), $1 \mu \mathrm{l}$ each of primers $\left(10 \mathrm{pmol} \mu \mathrm{l}^{-1}\right), 2.5 \mu \mathrm{l}$ $10 \times$ Taq polymerase buffer (NEB, Canada), $0.5 \mathrm{U}$ Taq DNA polymerase (NEB, Canada) and $200 \mu \mathrm{M}$ of each dNTPs (NEB, Canada). PCR cycling conditions maintained were as follows: initial denaturation at $95{ }^{\circ} \mathrm{C}$ for $2 \mathrm{~min}$, followed by cycle denaturation at $95{ }^{\circ} \mathrm{C}$ for $40 \mathrm{~s}$, annealing at $55^{\circ} \mathrm{C}$ for $40 \mathrm{~s}$, extension at $72{ }^{\circ} \mathrm{C}$ for $1.5 \mathrm{~min}$ for a total of 30 cycles and a final extension for $10 \mathrm{~min}$ at $72^{\circ} \mathrm{C}$. PCR products were purified using Nucleo-pore Genetix brand Sure Extract PCR clean-up/Gel extraction kit (Genetix Biotech, India) and used as a template for sequencing PCR using internal primer 1090R [GCTCGTTGCGGGACTTAACC] (Amann et al. 1995). Sequencing PCR was done with ABI PRISM Big Dye terminator ready reaction mix (Life Technologies, USA). The cycle extension products were purified following ethanol/EDTA/sodium acetate precipitation. The products were analysed on an Applied Biosystems ABI 3730xl DNA analyzer. Sequence data obtained were analysed and edited using Sequencher V4.10.1 (GeneCodes, USA).

The sequences were analysed in SILVA rRNA gene database project (https://www.arb-silva.de/ngs) (Quast et al. 2013). The sequences were aligned using the SILVA incremental aligner against the SILVA SSU rRNA SEED. The sequences with more than $98 \%$ similarity to each other were clustered into a single OTU and the longest sequence in each cluster was selected as representative OTUs. The nearest neighbours of representative OTUs were selected from NCBI by nucleotide BLAST search. Phylogenetic tree of representative OTUs was constructed using MEGA (5.5) software. The sequences of representative OTUs and those with bioactive potentials were submitted to NCBI (Accession No. KT818688 to KT818696, KX442647 to KX442650).

\section{Screening of isolates for the presence of NRPS and PKS genes}

One hundred and thirty-one isolates from sediment samples were screened for the presence of secondary metabolite biosynthetic genes such as Polyketide synthase (PKS) and non-ribosomal peptide synthetase (NRPS) genes. DNA was extracted from overnight grown cultures following standard phenol-chloroform method, and the quality of DNA was checked on $0.8 \%$ agarose gel (Sambrook and Russel 2001). The NRPS (700-800 bp) and PKS (1200-1400 bp) genes of the bacteria were amplified using primer combinations of A3F (GCSTACSYSATSTACACSTCSGG)A7R (SASGTCVCCSGTSCGGTAS) and K1F(TSAA GTCSAACATCGGBCA)-M6R(CGCAGGTTSCSGTACC AGTA), respectively (Ayuso-Sacido and Genilloud 2005). The PCR reaction was carried out in a $25 \mu \mathrm{l}$ reaction volume as mentioned above. PCR cycling conditions maintained were as follows: initial denaturation at $94{ }^{\circ} \mathrm{C}$ for $2 \mathrm{~min}$, followed by cycle denaturation at $94{ }^{\circ} \mathrm{C}$ for $30 \mathrm{~s}$, annealing at $59 / 55^{\circ} \mathrm{C}$ (respectively, for NRPS and PKS gene) for $30 \mathrm{~s}$, extension at $72{ }^{\circ} \mathrm{C}$ for $2 \mathrm{~min}$ for a total of 35 cycles and a final extension for $10 \mathrm{~min}$ at $72{ }^{\circ} \mathrm{C}$. The 
PCR products segregated on $0.8 \%$ agarose gel were stained with SYBR green and visualized in a gel documentation system (BioRad, USA).

\section{Preparation of organic extracts}

Organic extract of 131 isolates was prepared using ethyl acetate as solvent. Bacterial isolates for the production of secondary metabolites were prepared in basal medium. Briefly, $100 \mu \mathrm{l}$ of bacterial inoculum (1.0 OD at $600 \mathrm{~nm}$ ) prepared in basal medium was transferred into fresh medium $(100 \mathrm{ml})$ and incubated at $28 \pm 2{ }^{\circ} \mathrm{C}$ for 7 days in a rotary shaker maintained at $100 \mathrm{rpm}$. The supernatant from 7-day-old bacterial culture was mixed with equal volume of ethyl acetate and extracted by shaking at $180 \mathrm{rpm}$ for $1 \mathrm{~h}$. The ethyl acetate phase was separated and concentrated in a rotary evaporator under vacuum at $40{ }^{\circ} \mathrm{C}$. The residue thus obtained was weighed, stock solutions prepared in DMSO and maintained at $4{ }^{\circ} \mathrm{C}$ till further use.

\section{Cytotoxic and antibacterial properties}

The cytotoxicity of extracts was tested in triplicate in MCF7 breast cancer cell line using 3-(4,5-dimethylthiazole-2-yl)-2,5-diphenyltetrazolium chloride (MTT) assay. Briefly, MCF7 cells were cultured up to $50 \%$ confluence in a 96-well microplate containing Dulbecco's modified Eagle's medium (DMEM) supplemented with $10 \%$ foetal bovine serum (FBS). The cells were washed copiously with phosphate-buffered saline (PBS), and the medium was exchanged with DMEM $(10 \mathrm{ml})$ containing test compounds $(20 \mathrm{ppm})$. Cells exposed to DMEM or DMSO alone were maintained in separate wells as control. The cells were incubated for $24 \mathrm{~h}$ at $37{ }^{\circ} \mathrm{C}$ and subjected for MTT assay following standard protocol. Briefly, cells treated with test compounds were supplemented with $50 \mu \mathrm{l}$ of MTT solution ( $5 \mathrm{mg} \mathrm{ml}^{-1}$ ) prepared in PBS and kept for incubation under dark at $37^{\circ} \mathrm{C}$ for $3 \mathrm{~h}$. Subsequently, the viability of the cells was measured as a function of reduction of MTT to insoluble formazan by mitochondrial dehydrogenase enzyme of healthy cells. Formazan crystals were dissolved in Dimethyl Sulphoxide and the absorbance was recorded at $570 \mathrm{~nm}$ using a microplate reader (Biotech, USA).

The antibacterial property of the organic extracts against four isolates of multiple drug resistant bacteria, Staphylococcus aureus, Pseudomonas aeruginosa, Vibrio cholera and Escherichia coli, was tested using standard disc diffusion assay. Briefly, the $6 \mathrm{~mm}$ diameter paper discs impregnated with $100 \mu \mathrm{l}$ test compound (20 ppm) were placed over the surface of a Muller Hinton agar plate swabbed with test organisms. Paper discs impregnated with $100 \mu \mathrm{l}$ DMSO were also used as control. The plates were incubated for $24 \mathrm{~h}$ at $28 \pm 2{ }^{\circ} \mathrm{C}$ and the formation of clear zones around the discs was considered as the positive indication of inhibitory activity. The zone of inhibition around the discs was recorded after $24 \mathrm{~h}$ using Hi Antibiotic Zone Scale (Himedia, India).

\section{Results and discussion}

A total of 131 bacteria were isolated from sediment samples of AS in four different media. Higher number of bacterial colonies were observed on Oligo and basal medium, while only few colonies were found on starchbased medium (Fig. 2). The oligo and basal media were prepared in seawater and they differed in the concentration of nutrients. These two mediums used simple carbon and nitrogen sources, while starch casein and starch casein nitrate medium used more complicated nutrient sources. Different bacteria in marine environment differ in their function and accordingly their nutrient preference also varies. It is a widely accepted practice that in such cases, medium with different nutrient composition are used to retrieve maximum number of isolates.

Forty representative morphotypes of these isolates were identified using $16 \mathrm{~S}$ rRNA gene sequencing. Upon sequence analysis, they were clustered into seven OTUs, the relative abundance of which is represented in Fig. 3. Majority of the isolates belonged to $\gamma$-Proteobacteria, among which $53 \%$ were Pseudomonas sp. (1 OTU), $8 \%$ were Stenotrophomonas sp. (2 OTUs) and 3\% were Acinetobacter sp (Fig. 4). The second dominant group of bacteria isolated from AS sediment were Bacillales, with $31 \%$ Bacillus sp. (1 OTU) and 3\% Lysinibacillus sp. (1 OTU) (Fig. 4). A minor group of isolates represented 3\% of Micrococcus sp. (1 OTU). The previous reports from deep sea sediments of Pacific Ocean also reported the

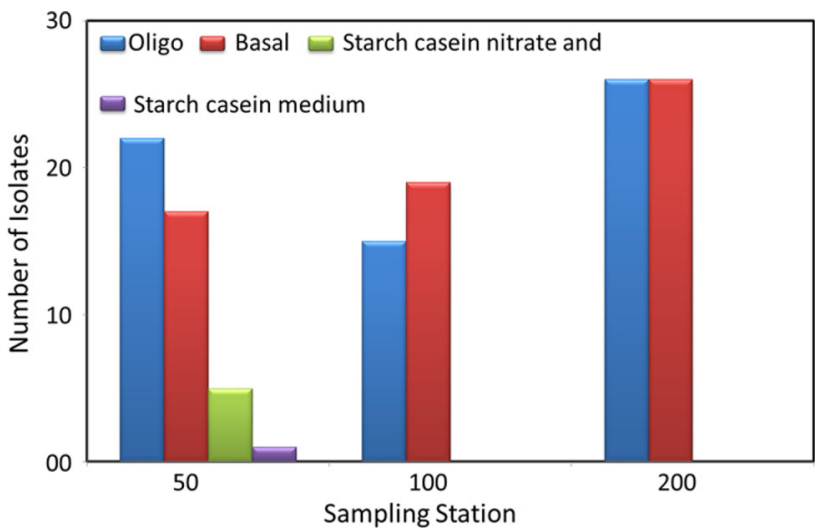

Fig. 2 Bar diagram showing the number of bacteria grown on different medium 
Fig. 3 Relative abundance of different OTUs of bacteria isolated from AS. The pie diagram is prepared based on Krona plot (Ondov et al. 2011) generate by analysis of sequences in SILVA rRNA gene database project (https://www. arb-silva.de/ngs)
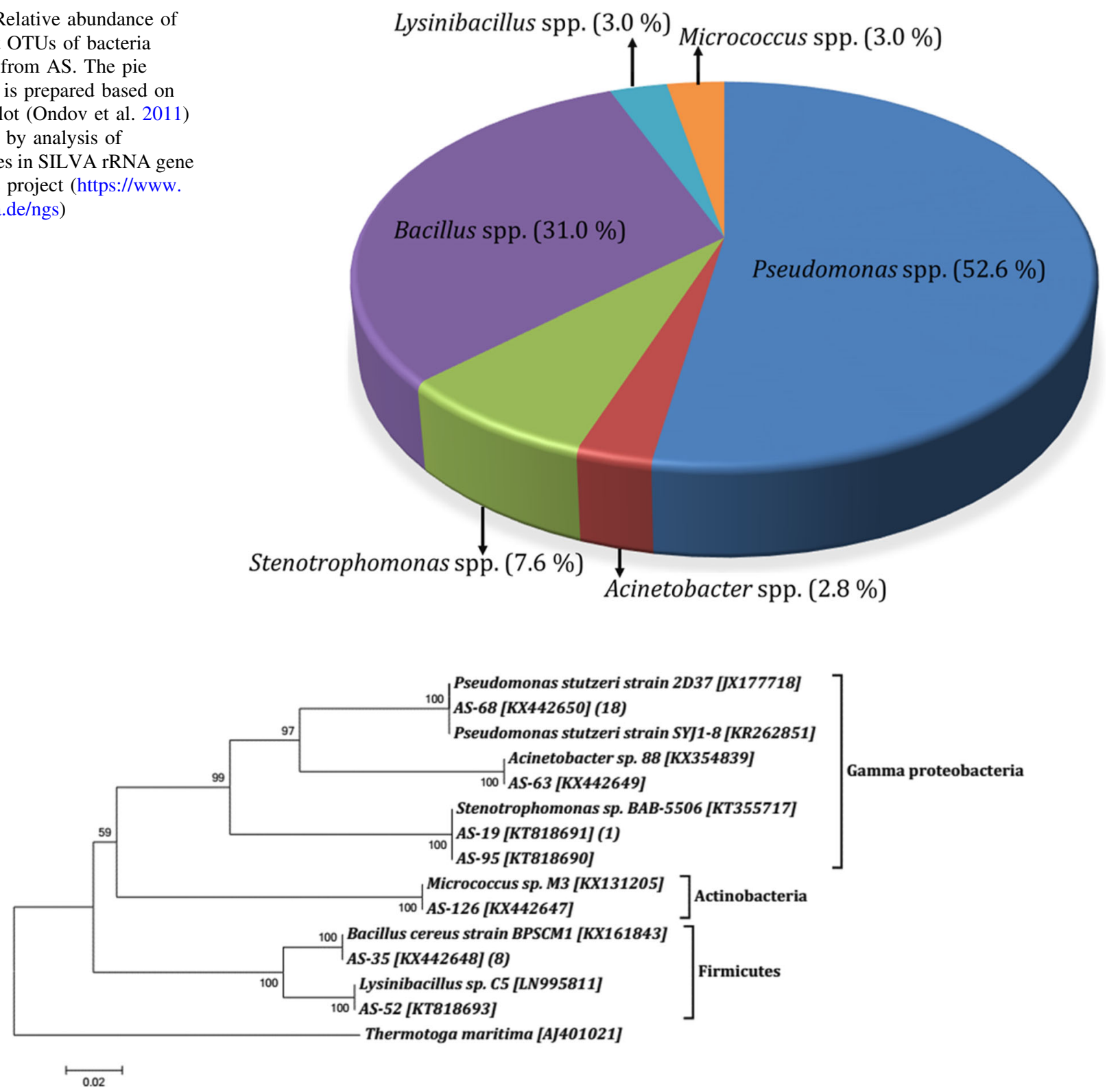

Fig. 4 Rooted neighbour-joining phylogenetic tree based on $16 \mathrm{~S}$ rRNA gene sequence of heterotrophic bacteria isolated from surficial sediment of AS. The numbers at each nodes are percentages

dominance of $\gamma$-Proteobacteria (Delong et al. 1997; Kato et al. 1996; Wang et al. 2004). The dominance of Firmicutes and $\gamma$-Proteobacteria in sediments of AS at 200, 500 and $1000 \mathrm{~m}$ depth of Goa coast was reported earlier (Divya et al. 2010). Divya et al. (2011) also confirmed the dominance of Proteobacteria in AS sediments by culture-independent clone library approach. Although the diversity of bacteria from different marine environments are reported, an ecological interpretation, including which group of bacteria are dominant in different environment (like oligotrophic, OMZ, vents, etc.), is limited. Such studies from soil environments indicated a positive correlation between indicating the levels of bootstrap support based on neighbour joining number of isolates in each OTUs

the carbon mineralization rate and Proteobacteria (Fierer et al. 2007; Ge et al. 2010). If this concept is taken, the AS sediment being a burial ground of organic carbon (Dale et al. 2015) may support the proliferation of Proteobacteria.

Although metagenomic approaches can provide more resolved status on diversity of bacteria, we used culturedependent methods as screening for bioactive potential was one of the objective of the present study. Here the bioactive potentials of all the isolates were studied at different levels; using molecular and cellular assays. It was observed that PKS genes. NRPS and PKS genes were present in 34 (26\%) analysis of 1000 resampled data sets. Number in bracket indicates the $\sim 40 \%$ of isolates showed the presence of either NRPS or 


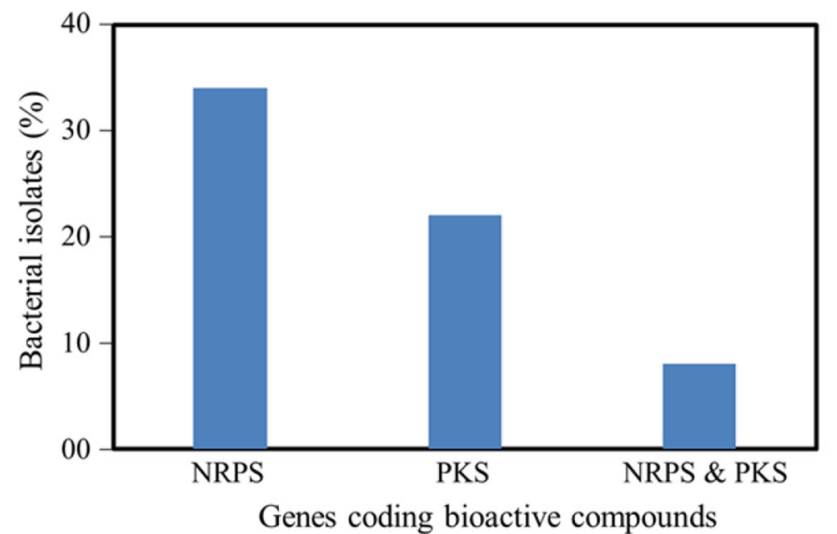

Fig. 5 Number of isolates showing the presence of NRPS, PKS genes

and $22(17 \%)$ isolates, respectively (Fig. 5). Interestingly, the presence of both NRPS and PKS genes was observed among 8 isolates (6\%). The presence of PKS and NRPS genes are reported in different microorganisms associated with sponges and marine sediments (Bull and Stach 2007; Schirmer et al. 2005). NRPS and PKS enzymes involved in the early phases of secondary metabolite biosynthesis pathways and synthesize common intermediary chemical structure, which then modified into diverse secondary metabolites (Wohllenben et al. 2012).

PCR screening for PKS and NRPS genes is advantageous as it permits the high-throughput screening for potential isolates, even if they do not produce the secondary metabolites under given culture conditions. However, the secondary metabolites synthesized through pathways other than PKS and NRPS may not be reflected in this assay. Though laborious, conventional bioassays permits the direct detection of secondary metabolites produced through different pathways. Therefore, in the present study, we used a combination of PCR and conventional bioassays. In MTT assay, nearly 50\% isolates showed medium or higher level of cytotoxicity in MCF7 breast cancer cell line (Fig. 6). Antibacterial activity was also shown by many isolates, while the intensity of activity varied between test organisms (Fig. 7). The organic extracts from 40 to $50 \%$ of the isolates showed medium or high level of antibacterial activity against E. coli and Pseudomonas sp., while the number of isolates with potential activity against Vibrio sp. and Staphylococcus sp. were 30 and $20 \%$, respectively.

These results indicate that sediments of the AS could be a promising source for novel bioactive molecules. The number of bacteria with bioactive potentials in sediments of AS are much higher compared to that reported from sediment of intertidal zone of China (Zheng et al. 2005) and bacteria associated with marine eukaryotes (Penesyan et al. 2009). Meanwhile, the results are comparable to that of sponge-associated bacteria; for example, more than $50 \%$

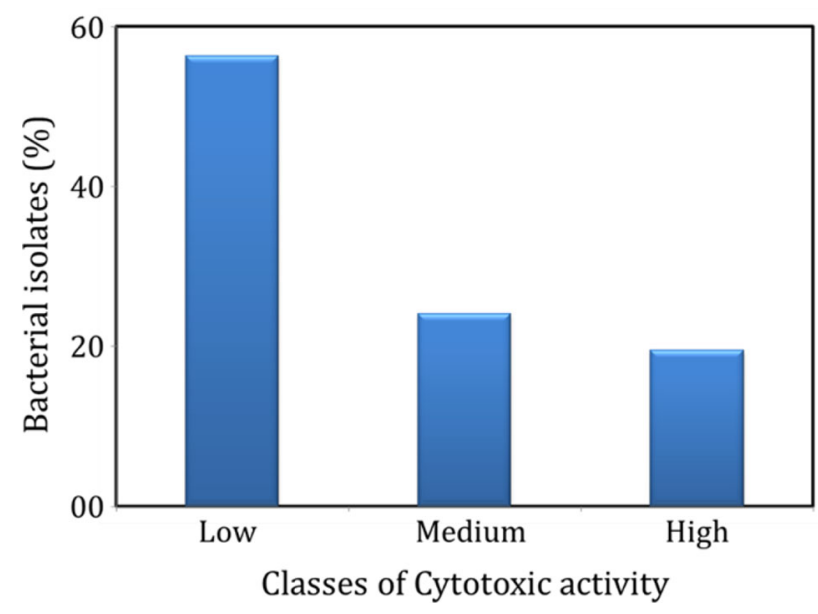

Fig. 6 Distribution of bacteria isolated from AS sediments, based on the cytotoxic activity of their ethyl acetate fraction in breast cancer MCF7 cells. The organisms were classified based on their cytotoxicity into low (0-10\% cytotoxicity), medium (10-30\% cytotoxicity) and high ( $>30 \%$ toxicity) cytotoxic groups

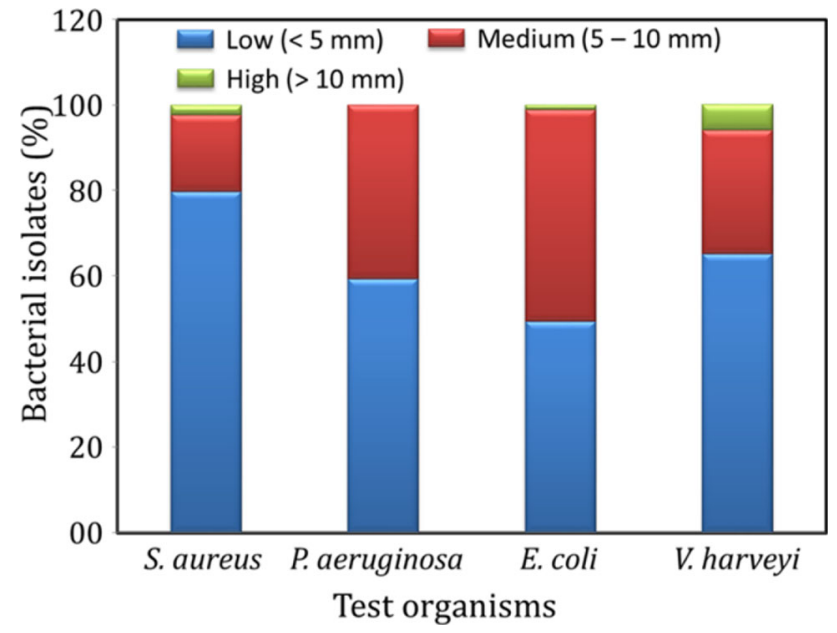

Fig. 7 Histogram showing the classification of bacteria isolated from AS sediment, based on the antibacterial activity of their ethyl acetate fraction against Staphylococcus aureus, Pseudomonas aeruginosa, Escherichia coli and Vibrio cholerae. The organisms were classified based on their antibacterial activity into low ( $<5 \mathrm{~mm}$ clearing zone), medium (5-10 mm clearing zone) and high (>10 mm clearing zone) activity groups

of bacteria isolated from the sponge Haliclona sp. and 34\% from Irciniidae sp. showed antibacterial properties (Ana et al. 2013; Thomas et al. 2010).

We ranked eight isolates as prospective ones for further investigation on novel bioactive potentials based on their high cytotoxicity (i.e. $>40 \%$ ) and antibacterial properties (Table 1). All the selected isolates except AS 8 had either NRPS or PKS gene. The NRPS and PKS gene cluster present in AS 8 may be novel and hence could not be amplified using the primer used in the study. Novel NRPs and PKS gene clusters have been reported recently from 
Table 1 Consolidated table showing the bioactive potentials of eight selected isolates

\begin{tabular}{|c|c|c|c|c|c|c|c|c|}
\hline \multirow[t]{2}{*}{ Activity } & \multicolumn{8}{|c|}{ Isolate no (AS-) } \\
\hline & 8 & 19 & 25 & 52 & 70 & 81 & 95 & 106 \\
\hline \multicolumn{9}{|l|}{ Presence of gene } \\
\hline NRPS & - & + & + & + & + & - & + & + \\
\hline PKS & - & - & + & - & - & + & - & + \\
\hline Cytotoxicity (dead cell, \%) & 41 & 39 & 44 & 43 & 45 & 48 & 43 & 50 \\
\hline \multicolumn{9}{|c|}{ Antibacterial activity (diameter of clearing zone in $\mathrm{mm}$ ) } \\
\hline Staphylococcus sp. & 0 & 12 & 7 & 6 & 0 & 6 & 0 & 6 \\
\hline Pseudomonas sp. & 0 & 7.5 & 0 & 0 & 0 & 7 & 0 & 6 \\
\hline E. coli & 6 & 8 & 0 & 0 & 0 & 6.5 & 0 & 0 \\
\hline Vibrio sp. & 0 & 21 & 0 & 6 & - & 7 & 6 & 0 \\
\hline
\end{tabular}

marine bacteria (Machado et al. 2015; Sun et al. 2016). Pseudomonas spp. AS 8, 106 and 70 displayed promising activity against MCF 7 cell line $(41,50$ and $45 \%$ mortality, respectively). The extract from the first two isolates was also moderately active against $E$ coli and Staphylococcus sp. respectively, while that of strain AS 70 was inactive against these bacterial pathogens. The bioactive potentials of marine Pseudomonas sp. and their application in aquaculture have been reported earlier (Chythanya et al. 2002; Pai et al. 2010). Many compounds have been extracted from marine organisms with cytotoxic and antibacterial activities (Zhao et al. 2013), while compounds with selective killing of prokaryotic or eukaryotic cells are rarely reported. Our results indicate that AS 70 is a potential source of bioactive molecules which can selectively kill the eukaryotic cells. Our studies also underline the importance of AS sediment as a source of bacteria with novel bioactive potentials.

Our study proposes sediments of AS with rich source of diverse bacteria as potential source for bioprospecting novel bioactive molecules. The organic extract from nearly $50 \%$ of the 131 isolates retrieved from sediments of AS showed cytotoxicity to human breast cancer cells MCF 7 and was bactericidal to human pathogens, E. coli and Pseudomonas sp. Eight isolates of Pseudomonas spp., Bacillus sp. and Lysinibacillus sp. showed exceptional cytotoxic/antibacterial properties. Further large-scale bioprospecting of bacteria from sediments of AS focused on the identification, purification and characterization of novel bioactive molecules will be appreciated.

Acknowledgements The authors thank the Director, CSIR-National Institute of Oceanography, Goa, Director CMLRE Kochi and the Scientist-in-Charge, CSIR-NIO Regional Centre, Kochi, for extending all the required support. This work was implemented with financial support of Department of Biotechnology, Govt. of India (BT/PR4953/AAQ/3/589/2012). SV is a recipient of CSIR-Nehru Postdoctoral fellowship.
Open Access This article is distributed under the terms of the Creative Commons Attribution 4.0 International License (http:// creativecommons.org/licenses/by/4.0/), which permits unrestricted use, distribution, and reproduction in any medium, provided you give appropriate credit to the original author(s) and the source, provide a link to the Creative Commons license, and indicate if changes were made.

\section{References}

Amann RI, Ludwig W, Schleifer K (1995) Phylogenetic identification and in situ detection of individual microbial cells without cultivation. Microbiol Rev 59:143-169

Ana ISE, Hardoim CCP, Xavier JR, Goncalves JMS, Costa R (2013) Molecular richness and biotechnological potential of bacteria cultured from Irciniidae sponges in the north-east Atlantic. FEMS Microbiol Ecol 85:519-536

Armstrong E, Yan L, Boyd KG, Wright PC, Burgess JG (2001) The symbiotic role of marine microbes on living surfaces. Hydrobiologica 461:37-40

Ayuso-Sacido A, Genilloud O (2005) New PCR primers for the screening of NRPS and PKS-I systems in actinomycetes: detection and distribution of these biosynthetic gene sequences in major taxonomic groups. Microb Ecol 49:10-24

Banse K, Naqwi SWA, Narvekar PV, Postel JR, Jayakumar DA (2014) Oxygen minimum zone of the open Arabian Sea: variability of oxygen and nitrite from daily to decadal timescales. Biogeosciences 11:2237-2261

Beedessee G, Ramanjooloo A, Marie DEP (2015) Marine natural products research in Mauritius: progress and challenges. Mar Chem 170:23-28

Bryant JA, Stewart FJ, Eppley JM, Delong EF (2012) Microbial community phylogenetic and trait diversity declines with depth in a marine oxygen minimum zone. Ecology 93:1659-1673

Bull AT, Stach JEM (2007) Marine actinobacteria: new opportunities for natural product search and discovery TRENDS. Microbiology 15:491-499

Canfield DE et al (2010) A cryptic sulfur cycle in oxygen-minimumzone waters off the chilean coast. Science 330:1375-1378

Childress JJ, Sieibel BA (1998) Life at stable low oxygen levels: adaptations of animals to oceanic oxygen minimum layers. J Exper Biol 201:1223-1232 
Chythanya R, Karunasagar I, Karunasagar I (2002) Inhibition of shrimp pathogenic vibrios by a marine Pseudomonas I-2 strain. Aquaculture 208:1-10

Codispoti LA, Brandes JA, Christensen JP, Devlol AH, Naqwi WSA, Paerl HW, Yoshinari T (2001) The oceanic fixed nitrogen and nitrous oxide budgets: moving targets as we enter the anthropocene? Sci Marina 65:85-105

Dale AW et al (2015) Organic carbon production, mineralization and preservation on the Peruvian margin. Biogeosciences 12:1537-1559

Daniel R (2004) The soil metagenome-a rich resource for the discovery of novel natural products. Curr Opin Biotechnol 15:199-204

Debbab A, Aly AH, Lin WH, Proksch P (2010) Bioactive compounds from marine bacteria and fungi. Microb Biotechnol 3:544-563

Delong EF, Franks DG, Yayanos AA (1997) Evolutionary relationships of cultivated psychrophilic and baraophilic deep sea bacteria. Appl Environ Microbiol 63:2105-2108

Divya B, Soumya KV, Nair S (2010) 16SrRNA and enzymatic diversity of culturable bacteria from the sediments of oxygen minimum zone in the Arabian Sea. Antonie Van Leeuwenhoek 98:9-18

Divya B, Parvathi A, Loka Bharathi PA, Nair S (2011) 16S rRNAbased bacterial diversity in the organic-rich sediments underlying oxygen-deficient waters of the eastern Arabian Sea. World J Microbiol Biotechnol 27:2821-2833

Fierer N, Bradford MA, Jackson RB (2007) Toward and ecological classification of soil bacteria. Ecology 88:1354-1364

Fieseler L, Quaiser A, Schleper C, Hentschel U (2006) Analysis of the first genome fragment from the marine sponge-associated, novel candidate phylum Poribacteria by environmental genomics. Environ Microbiol 8:612-624

Ge Y, Chen C, Xu Z, Eldridge SM, Chan KY, He Y, He JZ (2010) Carbon/nitrogen ratio as a major factor for predicting the effects of organic wastes on soil bacterial communities assessed by DNA-based molecular techniques. Environ Sci Pollut Res Int $17: 807-815$

Kato C, Inoue A, Horikoshi K (1996) Isolating and characterizing deep-sea marine microorganisms. Trends Biotechnol 14:6-12

Lam P et al (2009) Revising the nitrogen cycle in the Peruvian oxygen minimum zone. Proc Natl Acad Sci 106:4752-4757

Lane DJ (1991) 16S/23S rRNA sequencing. Nucleic acid techniques in bacterial systematics. Wiley, New York

Lemos ML, Toranzo AE, Barja JL (1985) Antibiotic activity of epiphytic bacteria isolate from intertidal seaweeds. Microb Ecol 11:149-163

Machado H, Sonnenschein EC, Melchiorsen J, Gram L (2015) Genome mining reveals unlocked bioactive potential of marine Gram-negative bacteria. BMC Genom 16:1-12

Mehbub MF, Lei J, Franco C, Zhang W (2014) Marine sponge derived natural products between 2001 and 2010: trends and opportunities for discovery of bioactives. Mar Drugs 12:4539-4577

Ondov BD, Begman NH, Phillippy AM (2011) Interactive metagenomic visualization in a web browser. BMC Bioinform 12:385
Pai SS et al (2010) Penaeus monodon larvae can be protected from Vibrio harveyi infection by pre-emptive treatment of a rearing system with antagonistic or non-antagonistic bacterial probiotics. Aquac Res 41:847-860

Paulmier A, Ruiz-Pino D (2009) Oxygen minimum zones (OMZs) in the modern ocean. Prog Oceanogr 80:113-128

Penesyan A, Marshall-Jones Z, Homstrom C, Kjeleberg S, Egan S (2009) Antimicrobial activity observed among cultured marine epiphytic bacteria reflects their potential as a source of new drugs FEMS. Microbiol Ecol 69:113-124

Quast C et al (2013) The SILVA ribosomal RNA gene database project: improved data processing and web-based tools. Nucleic Acids Res 41:D590-D596

Sambrook J, Russel DW (2001) Molecular cloning: a laboratory mannual vol, 3rd edn. Cold Spring Harbour Laboratory, New York

Santos-Gandelman FJ, Giambiagi-deMarval M, Oelemann MRW, Laport SM (2014) Biotechnological potential of sponge-associated bacteria. Curr Pharm Biotechnol 15:143-155

Schirmer A, Gadkari R, Reeves CD, Ibrahim F, DeLong EF, Hutchinson R (2005) Metagenomic analysis reveals diverse polyketide synthase gene clusters in microorganisms associated with the marine sponge Discodermia dissoluta. Appl Environ Microbiol 71:4840-4849

Schneider C-C, Bush-Brown S (2003) How is deep ocean life affected by oxygen minimum zones. Traprock $2: 19-23$

Sponga F, Cavaletti L, Lazzarini A, Borghi A, Ciciliato I, Losi D, Marinelli F (1999) Biodiversity and potentials of marine-derived microorganisms. J Biotechnol 70:65-69

Sun Y, Tomura T, Sato J, Iizuka T, Fudou R, Ojika M (2016) Isolation and biosynthetic analysis of haliamide, a new PKSNRPS hybrid metabolite from the marine myxobacterium Haliangium ochraceum. Molecules 21:59

Thakur A, Thakur N, Indap M, Pandit R, Datar V, Müller WG (2005) Antiangiogenic, antimicrobial, and cytotoxic potential of sponge-associated bacteria. Mar Biotechnol 7:245-252

Thomas TRA, Kavlekar DP, Lokabharathi PA (2010) Marine drugs from sponge-microbe assciation- $\mathrm{a}$ review. Mar Drugs 8:1417-1468

Wang F, Wang P, Chen M, Xiao X (2004) Isolation of extremophiles with the detection and retreival of Shewanella strain in deep-sea sediments from the west Pacific. Extremophiles 21:165-168

Woebken D et al (2008) A microdiversity study of anammox bacteria reveals a novel Candidatus Scanlindua phylotype in marine oxygen minimum zones. Environ Microbiol 10:3106-3119

Wohllenben W, Mast Y, Muth G, Rottgen M, Stegmann E, Weber T (2012) Synthetic biology of secondary metabolite biosynthesis in actinomycetes: engineering precursor supply as a way to optimize antibiotic production. FEBS Lett 586:2171-2176

Zhao M et al (2013) Cytotoxic and antibacterial cembranoids from a South China Sea soft coral, Lobophytum sp. Mar Drugs 11:1162-1172

Zheng L, Han X, Chen H, Lin W, Yan X (2005) Marine bacteria associated with marine microorganisms: the potential antimicrobial resources. Ann Microbiol 55:119-124 